\title{
Research on the Current Situation and Countermeasures for the Development of Chinese Apparel Industry
}

\author{
Jun YIN \\ Wuhan Textile University, Wuhan, 430073, China \\ email: 12408113@qq.com
}

Key Words: Chinese apparel industry; international brand; current situation; countermeasures

\begin{abstract}
In recent years, the rapid development of Chinese apparel industry has made China the world's largest producer, consumer and exporter of clothing, but it is still a large manufacturer country and a small country of brand which lacks its own international brands. Therefore, besides keeping the amount of production and export, at the same time, Chinese apparel industry has to realize the necessity of creating an international brand. In addition, as for the coming of the post-quota era for the world garment trade and the development trend of garment industrial pattern, they all provide a better environment and better growth space for international trade cooperation for the Chinese apparel industry to create an international brand. This paper mainly focuses on the strategic research for Chinese apparel industry, in order to create an international brand, and hoping that it can achieve this goal as soon as possible.
\end{abstract}

\section{Introduction}

Chinese apparel industry has tried very hard to achieve the brand internationalization in recent years, but in today's international markets, the sales of clothing with our own brand is very low. Before 2001, our country is not a member of world garment association which has never taken part in the world conference on garment. So in the statistics of international garments, we can never find China and Chinese brands. [1] As the world's largest apparel producer and exporter, China yields with large production, but for the most part, it just processes for foreign brands. Since joining the WTO, some apparel enterprises has made some more solid work in the brand internationalization, such as the internationalization of the brand registration, the internationalization of the design, participating in international fashion exhibitions at home and abroad, recruiting world-class designers and image spokesperson of international brands, adopting the strategy of going out in some individual companies, etc., but it is not enough to create an international brand. [2]It is very difficult for Chinese clothing brand to develop not only in developed countries of Europe and America, but even in Eastern Europe and other less-developed countries. Today, after our accession to the WTO, it takes a lot of time for Chinese clothing brands to enter the markets without a hitch, gradually build up reputation and create a truly international brand.

\section{Problems Existing in the Development of Chinese Apparel Industry}

\section{A. Low-level industrialization of product and the enterprise}

At present, the Chinese apparel industry mainly consists of small businesses with the vast majority of materials processing products. [3] In terms of products, Chinese apparel industry lacks professional competition such as technical competition, skills, ability competition, skill competition and craft competition. To be specific, first of all is the lack of technology, the second is the imperfect ability structure, the third is the limited skill, and the last is the low craft level which means the comprehensive performance of the product is not high. In terms of enterprises, firstly, the 
problems are the limited size and the low quality of Chinese clothing enterprises. [4]As is known to all, the development of enterprise now relies on the updated speed and quality of knowledge and technology, but Chinese clothing production at present is mainly in small businesses with limited capital and weak ability for technical renovation and transformation. And usually small businesses are more easily driven by profit and ignore input in science, technology and talent - training which leads to the high staff liquidity. With good technology they can not have long-term stable development. [5]Therefore, with simple and crude means of production and backward management, most enterprises of Chinese apparel industry can not achieve modernization of management. Because the parents' workshop-style of management accounts for a considerable proportion and the overall quality of the competition is not high, it is difficult for many clothing enterprises to run business and develop. Secondly, the management of clothing enterprise is inadequate. The proposed management here includes both the enterprise's own management and the management of the enterprise from the industry and government. The former is different from person to person; the latter is still characterized with a blind production by a lack of the collective coordination administration of the industry. [6]On one hand, government's support is not enough; on the other hand, each enterprise fights its own battle with high cost and low degree of specialization of social division of labor. Thirdly, clothing enterprises in the capital market lack competitions. For the apparel industry, the government has not set up corresponding policy-based financial support system and lacks funds to serve small and medium enterprises. And enterprise itself is the lack of brand, culture, and technology and enterprise group finance credit, lack of initiative in the capital of the securities market. And the enterprise itself is also short of the finance credit of enterprise group which combines brand, culture and technology. It also lacks initiative in the capital stock market.

\section{B. The level of three kinds of materials is low with little technological content.}

Namely, three materials of clothing production are fabrics, auxiliary materials, and accessories material which form the foundation of clothing production. Therefore, one of the key in the competition of apparel industry is the competition of them. Chinese clothing brand can't enter the international market; the main reason is that the quality of the three materials fails meeting the requirement. At present, three materials China produces accounts for about $40 \%$ to $45 \%$, but when processing for international clothing brand, most are imported fabrics which means processing materials supplied by clients, for haute couture, it is as high as more than $70 \%$.So, what is the problem for the production of three materials in Chinese apparel industry? First of all, the production of three materials in Chinese apparel industry has not formed the innovation developmental system without cultural characteristics and modernization, especially in technology, for it is almost completely subject to foreign textile clothing field. Second, due to the relatively short development history of the three materials in Chinese apparel industry, so the textile industry and material industry of garment accessories relatively fall behind. There is no one enterprise undertaking the leading role to lead the development of the whole industry. Third, Chinese apparel industry lacks material and technology. For example, the division of labor of three material industries is not professional, the industrial structure is unreasonable and market pulling enterprises are the dominant.

\section{The brand construction falls behind.}

Chinese apparel industry has world-class products but without world-class brands. It is not because of the difference of the quality and performance of the product itself, but the difference of brand awareness and brand strategy. As the world's largest clothing producer and exporter, Chinese apparel industry is still at the early stage of the brand construction. When Chinese apparel industry also enters the brand competition stage like other industries, it is mainly for the underlying 
consumers. High-level consumers still don't care about Chinese indigenous brands. The main reason is that the lack of brand awareness in Chinese apparel industry leads to the absence of enterprise brand autonomy. And the lack of a strong brand initiative means no right to speak in market competition, especially compared with international clothing predators, Chinese clothing brand obviously lacks brand competitiveness. It is because the brand construction lags which leads directly to the situation where many Chinese clothing enterprises work as employees for foreign brands. Words like OEM, processing base, manual workshop, intensive labor and so on become the characteristics of the clothing power.

\section{The culture taste of clothing is low.}

Two pillars of Chinese national culture are clothing culture and diet culture. Chinese clothing culture has rich background, but lacks enough development, flourishing atmosphere and strong publicity. The powerful production capacity does not match the influence and appeal of Chinese clothing culture. Within the industry, there are not professional newspapers and magazines, as well as large fashion shows with rich cultural connotation. Within enterprises, they have weak service consciousness and strong sense of investment and profits. But for the product brand, cultural connotation they invest is simple, pale and superficial.

\section{The brand strategy to create an international brand for Chinese apparel industry}

\section{A. Reference Model}

Chinese clothing enterprises can draw lessons from the pattern to strengthen the consciousness of brand strategy within the enterprise from each aspect and improve the capacity of brand strategy management of corporation which makes Chinese clothing brands enter the international market more systematically and become one of the international brands for a long time.

\begin{tabular}{|l|l|}
\hline \multicolumn{1}{|c|}{ Traditional brand management } & \multicolumn{1}{c|}{ Brand leaders hip model } \\
\hline Tactical management & Strategic management \\
\hline tactical,timely response & strtegic,far-sighted \\
\hline $\begin{array}{l}\text { junior brand manager, } \\
\text { experience shortage }\end{array}$ & $\begin{array}{l}\text { senior brand manager, } \\
\text { in the enterprise top }\end{array}$ \\
\hline coceptual model-- brand image & conceptual--brand as sets \\
\hline focus on short-termbenefits & developing brand as sets evaluation \\
\hline limited focus & broad field of vision \\
\hline focus on a single product and market & $\begin{array}{l}\text { management across products and } \\
\text { markets }\end{array}$ \\
\hline single brand stucture & conplex brand stuctures \\
\hline focus on single brand & multiple brands-categories management \\
\hline multi-nations--brand management & global view \\
\hline $\begin{array}{l}\text { brand manager in charge cormunication } \\
\text { groups }\end{array}$ & $\begin{array}{l}\text { specific leadership for communication } \\
\text { group }\end{array}$ \\
\hline brand is in a fuctional organization & charged by individual or cross- groups \\
\hline extemal- oriented vision & attached to the culture and values \\
\hline strategic promotion-s ales & strategic promotion- brand identity \\
\hline promoted by sales and markets & promoted by brandidentity \\
\hline
\end{tabular}

Table 1 Comparison between brand leadership model and the management mode 


\section{B. Pay attention to the brand core values}

A brand enjoys popular support because it is carrying a core value which makes consumers resonate. Just like a person, the brand must have its own ideological values. The core values just reflect the spirit of the brand which resonates with consumers. The core values should reflect deeper psychological needs of target-consumers and provide them with deeper satisfaction which can not be qualified. Therefore, it is also the foothold that builds brand strategy. At present, the Chinese apparel industry does not pay much attention to establishing the core values of the brand. For example, in the suit market, most brands advertise successful and noble men even suits of just two or three hundred yuan. This kind of core values without great difference does not have commercial power. In today's society, the consumer demand becomes more and more personalized. A brand can not attract all consumers' eyes. It is enough when a brand core value touches segment consumers. When establishing the brand core values, it is suggested that Chinese apparel industry should combine with Chinese traditional culture, manners and customs and national features and then pass the core values to the target consumer groups. In the international clothing market, there are some oriental elements which can not form a system. However, the Chinese apparel industry can take advantage of this to build international clothing brands in this field.

\section{Brand Identification System}

If a brand wants to be sustainable, a core value with a specific symbolic significance is not enough. It also needs a stable and varying identification system. Brand identification system requires taking the brand identification as a long and lasting measure and strategy so as to form the brand maintain the sustainability and realize the capitalization of the brand. Here is the brand identification system mentioned by David A. Aake and Erich Joachimsthaler in their book Brand Leadership (see picture 1), which can be used for reference by Chinese clothing brands.

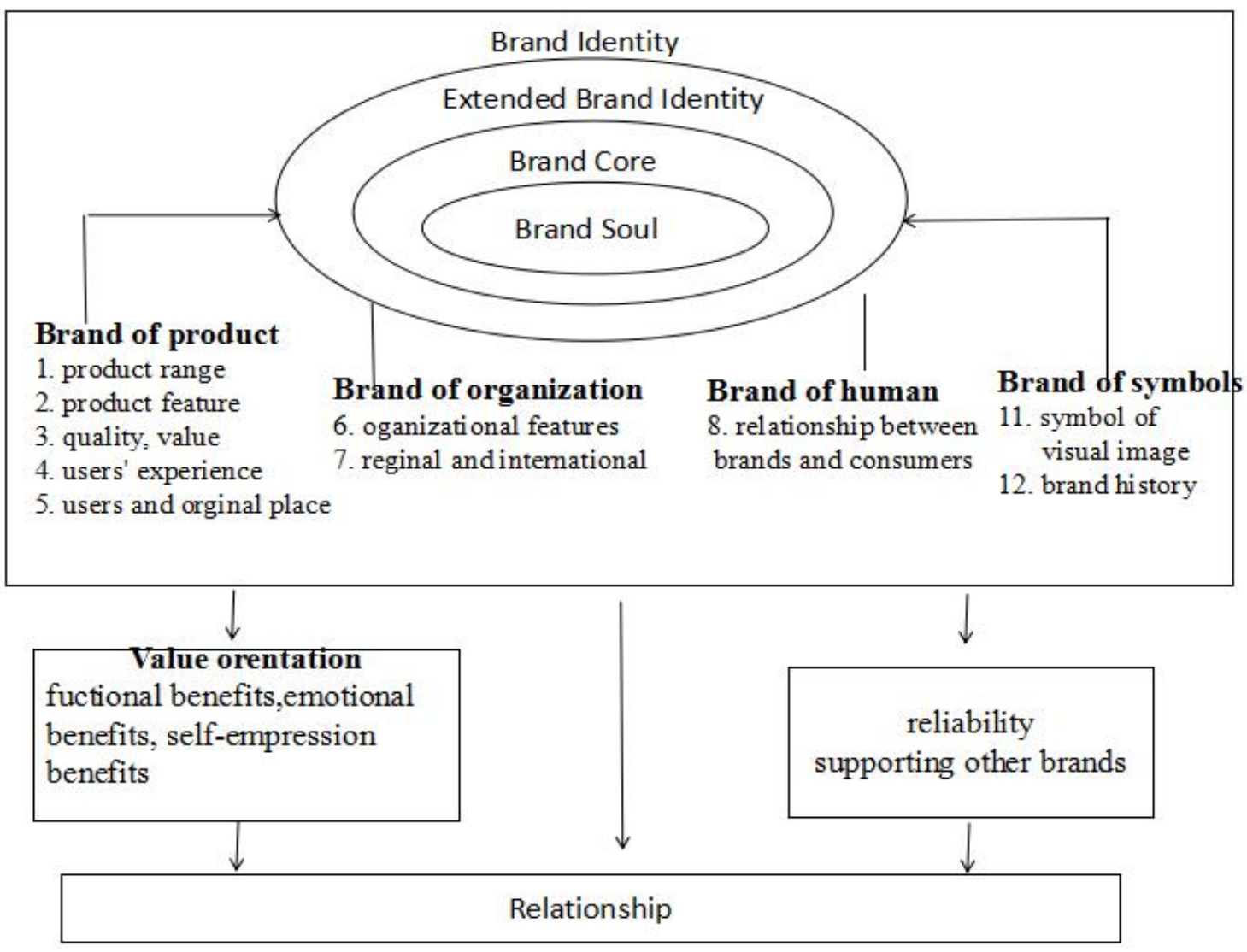

Table 2: Brand Identification System 
This brand identification system divides 12 items of brand recognition into four categories, namely the brand of product, the brand as an organization, the brand as a person and the brand as a symbol; the structure of brand identification includes the core identity, extended identity and brand core; in addition to functional interests, the value orientation also includes emotional benefits and self-expression benefits; and the last relationship reflects the relationship between brands and consumers.

\section{Brand Asset Management}

According to a survey of Fortune, we are informed that the ratio of tangible assets and intangible assets has changed a lot. That is, 20 years ago, tangible assets account for $95 \%$ of a company's total market value while intangible assets account for only 5\%. But in 2001, the proportion of tangible assets falls to $28 \%$ while the proportion of intangible assets rises sharply to $72 \%$. It is not difficult to draw the conclusion that brand value constitutes more and more of the total value. However, we should also notice that brands in different industries play different roles. For perfume, brand is particularly important. To some degree, the brand of perfume is actually its total value. For instance, if we put the brand of Chanel aside, then it will be nothing but scented water. It is the same with garment industry in which brand is more and more crucial and intangible assets constitute more and more of the total value. Thus, it is very urgent for garment enterprises to ensure competitive edge and long-term profit by improving brand asset management which is defined as brand property that is related to brand name and symbol and attaches to certain products or services.

\section{Conclusion}

To build their own international brand, Chinese garment enterprises should firstly strengthen construction of organization, association and professional committee and attach much importance to information platform and informatization. After that, they should also revise their quality supervision and standard to bring them in line with international standards. Besides, promoting brand awareness, which exactly means grasping basic patterns of brand creation and management, and the strategic marketing construction in line with domestic marketing situation are also crucial. Another important element of brand creation is their talent. Thus, they are considered to carry out more activities about education, training and exchange which expectedly conduce to their professionalism and international cooperation.

\section{References}

[1] Riehard Anker,Igor Chernyshev,Philippe Egger,Farhad Mehran,Joseph Ritter.Measuring decent work with statistical indicators. International Labor Review . 2003

[2] McGregor D.The Human Side of Enterprise. Journal of Women s Health . 1960

[3] Bentler PM,Chou CP.Practical issues in structural modeling. Sociological Methods and Research . 1987

[4] Alderfer,P Clayton.Existence, Relatedness and Growth: Human Needs in Organizational Settings. Journal of Women s Health . 1972

[5] Douglas T. Hall,Khalil E. Nougaim.An examination of Maslow's need hierarchy in an organizational setting. Journal of Organizational Behavior . 1968

[6] Graen G.Instrumentality theory of work motivation: some experimental results and suggested modifications. The Journal of applied psychology. 1969 